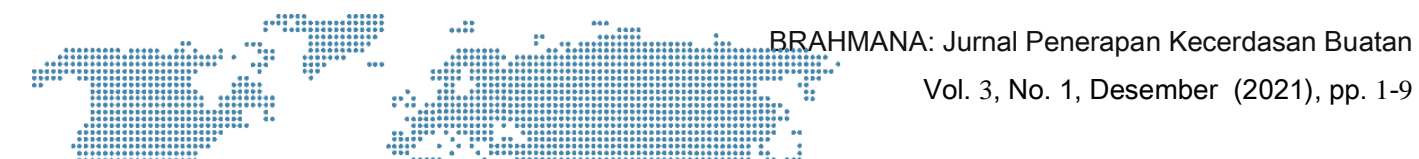

\title{
Analísis Data Mining Menentukan Penerima Bantuan Langsung Tưnai pada Desa Pamatang Purba dengan Algoritma C 4.5
}

\author{
Rajes Wasinson Sinaga ${ }^{1}$, Riki Winanjaya ${ }^{2}$, Susianti ${ }^{3}$

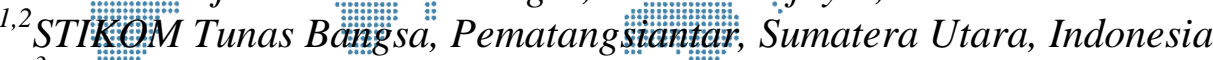 \\ ${ }^{3}$ AMIXK Tunas Bangsa, Pematangsiantar, S.umatera Utara, Indonesia \\ ${ }^{1}$ rajessinagä3@gmail.com, 2winanjaya85@gmail.com, ${ }^{3}$ susianiatbl@gmail.com
}

\begin{abstract}
In tackling the problem of poverty, the Government implements a cash direct assistance program (BLT) which is a program that provides cash assistance (subsidies) to poor households if they meet the requirements set out in the program. The purpose of this study is to determine whether the family is still eligible or does not receive direct cash assistance (BLT), where there are still many other poor families who have not had the opportunity to receive this assistance program. Data source obtained from The Office of Lurah Pamatang Purba. The method used in the study was data mining technique with C4.5algorithm that was impelemented with RapidMiner application. The attributes used in determining the eligibility of the family are still eligible or do not receive assistance in this assistance program, namely income, age, marital status, employment, recipients of Bansos, bpjs recipients. The results of the classification using the C4.5 algorithm and testing with softwareRapidMiner is the most influential factor in the eligibility of recipients of the direct cash assistance program (BLT).
\end{abstract}

Keywords: C4.5 algorithm, Data mining, direct cash assistance (BLT)

\begin{abstract}
Abstrak
Pemerintah melaksanakan Program bantuan langsung tunai (BLT) yang merupakan bantuan program yang memberikan bantuan (subsidi) tunai kepada rumah tangga miskin jika mereka memenuhi persyaratan yang ditetapkan dalam program. Tujuan penelitian ini untuk menentukan apakah keluarga tersebut masih layak atau tidak menerima bantuan lansung tunai (BLT) ini, dimana masih banyak keluarga tidak mampu lainnya yang belum berkesempatan menerima program bantuan ini. Sumber data yang diperoleh dari Kantor Lurah Pamatang Purba. Metode yang digunakan dalam penelitian adalah teknik data mining dengan algoritma C4.5 yang diimpelementasikan dengan aplikasi RapidMiner. Atribut yang digunakan dalam menentukan kelayakan keluarga tersebut masih layak atau tidak menerima bantuan program bantuan ini yaitu penghasilan, umur, status pernikahan, pekerjaan, penerima Bansos, penerima BPJS. Hasil dari klasifikasi menggunakan algoritma C4.5 dan pengujian dengan software RapidMiner maka didapatkan faktor yang paling berpengaruh terhadap kelayakan penerima Program bantuan langsung tunai (BLT).
\end{abstract}

Kata Kunci: Algoritma C4.5, Data mining, bantuan lansung tunai (BLT)

\section{Pendahuluan}

Data mining merupakan disiplin ilmu yang mempelajari metode untuk mengekstrak pengetahuan atau menemukan pola dari suatu data[1]. Klasifikasi merupakan salah satu tugas dari datamning. Klasifikasi adalah menemukan sebuah data record data baru ke salah satu dari beberapa katagori (kelas) yang telah didefinisikan sebelumnya [2]. Metode algoritma C4.5 merupakan metode klasifikasi yang cukup baik karena memiliki tingkat akurasi yang lebih baik. Algoritma C4.5 merupakan algoritma yang digunakan untuk membentuk pohon keputusan. Pohon Keputusan (Decision Tree) merupakan algoritma pengklasifikasian yang sering 

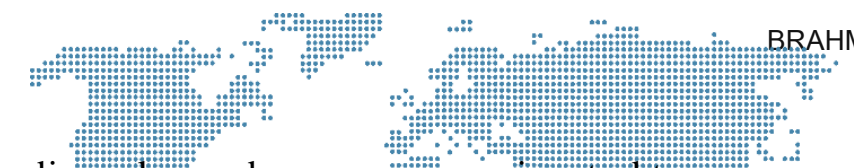

BRAHMANA: Jurnal Penerapan Kecerdasan Buatan Vol. 3, No. 1, Desember (2021), pp. 1-9

digunakan dan menpunyau struktur jang sederhana dan mudah untuk diinterprëtasikan. Bantuan L Eangsung Tunai (BLT) dapat diartikan pemberian

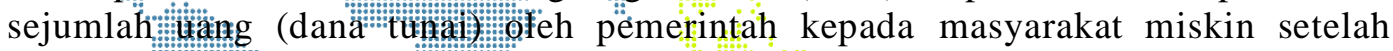
pemerintaitu menaikkan harga BBM atau terjadinya suatu musibah besar yang

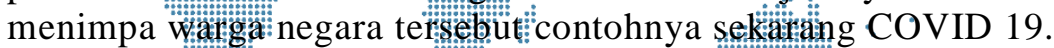

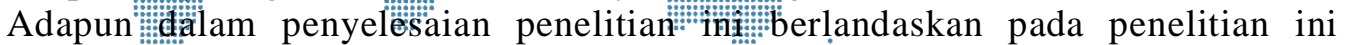
berlandaskan pada penelitian terdahulu. Menürut penelitian yang dilakukan oleh Panji Bimo Nugroho Setio, Dewi Retno Sari Saputro, Bowo Winarno (2020) yang berjudul tenyang "Klasifikasi dengan Pohon Keputusan Berbasis Algoritme C4.5". Pohon keputusan berguna untuk mengeksplorasi data, menemukan hubungan tersembunyi antara sejumlah calon variabel input dengan sebuah variabel target. [3] dengan judul "Analisa Kelayakan Penerima Program Keluarga Harapan (PKH) Menggunakan Algoritma C4.5". Hasil dari klasifikasi menggunakan algoritma C4.5 dan pengujian dengan software RapidMiner maka didapatkan faktor yang paling berpengaruh terhadap kelayakan penerima Program Keluarga Harapan (PKH) adalah jumlah penghasilan (C1) dengan nilai gain sebesar 0,51827179. [4], dengan judul "Implementasi Data Mining Dengan Algoritma C4.5 Untuk Penjurusan Siswa (Studi Kasus: SMA Negeri 1 Pontianak)". Pada penelitian ini, penjurusan siswa diklasifikasi berdasarkan nilai tes akademik MTK, IPA, dan IPS, nilai rata-rata rapor SMP untuk mata pelajaran MTK, IPA, dan IPS, nilai Ujian Nasional SMP untuk mata pelajaran MTK dan IPA, dan minat siswa. Berdasarkan hasil penelitian, didapatkan hasil klasifikasi penjurusan siswa yang sudah diuji sesuai dengan tingkat akurasi sebesar $89.74 \%$. Namun setelah melakukan penelitian penulis melihat beberapa kekurangan pada pelaksanaan pemberian bantuan langusng tunai (BLT) karena proses penentuannya masih dilakukan secara manual. Sehingga adanya penerima bantuan yang masih tergolong mampu yang menerima bantuan tersebut. Maka dengan itu Metode Algoritma C4.5 diharapkan dapat membantu perangkat Desa untuk menentukan penerima bantuan langsung tunai (BLT). Penelitian ini diharapkan dapat membantu Kantor Lurah Nagori Pamatang Purba untuk menentukan penerima bantuan langsung tunai (BLT) yang efektif dan tepat. Supaya untuk kedepannya keputusan yang diambil oleh kantor lurah tepat sasaran ,karena sudah melalui proses perhitungan yang akurat.

\section{Metodologi Penelitian}

\subsection{Data Mining}

Data Mining adalah proses yang menggunakan teknik statistik, matematika, kecerdasan buatan, machine learning untuk mengekstraksi dan mengidentifikasi informasi yang bermanfaat dan pengetahuan yang terkait dari berbagai database besar [5]. Terdapat beberapa istilah lain yang memiliki makna sama dengan data mining, yaitu Knowledge discovery in databases (KDD), ekstraksi pengetahuan (knowledge extraction), Analisa data/pola (data/pattern analysis), kecerdasan bisnis (business intelligence) dan data archaeology dan data dredging [6]. Metode algoritma C4.5 merupakan metode klasifikasi yang cukup baik karena memiliki tingkat akurasi yang lebih baik.

\subsection{Pohon Keputusan}

Pohon Keputusan (Decision Tree) merupakan algoritma pengklasifikasian yang sering digunakan dan mempunyai struktur yang sederhana dan mudah untuk diinterpretasikan. Pohon yang terbentuk menyerupai pohon terbalik, dimana akar (root) berada di bagian paling atas dan daun (leaf) berada di bagian paling bawah. Pohon keputusan merupakan model klasifikasi yang berbentuk seperti pohon, dimana pohon keputusan mudah untuk dimengerti meskipun oleh pengguna yang belum ahli sekalipun dan lebih efisien dalam menginduksi data [7][8]. Pohon 


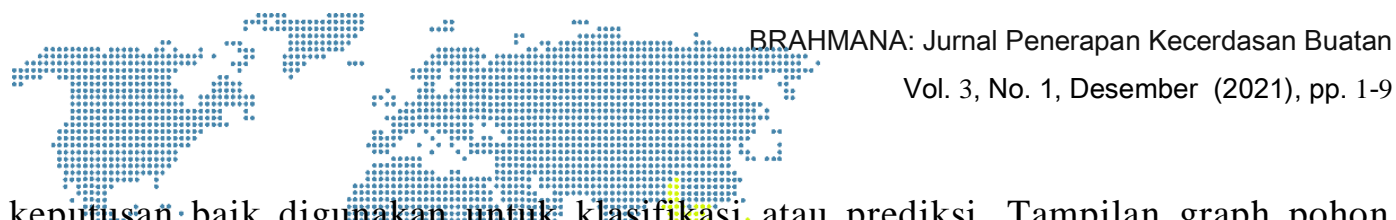

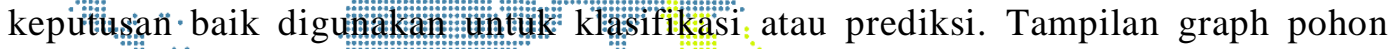
keputusẳitidapat dilihat pada Gämbar 1. dibawah ini:

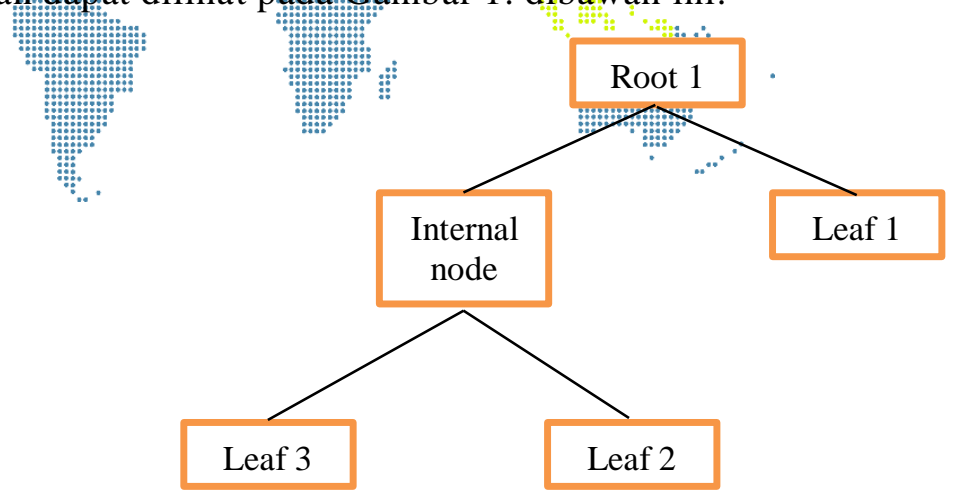

Gambar 1. Konsep Dasar Graph Pohon Keputusan

\subsection{Metode Algoritma $\mathbf{C 4 . 5}$}

Algoritma C4.5 merupakan algoritma yang digunakan untuk membentuk pohon keputusan. Sedangkan pohon keputusan dapat diartikan sebagai suatu cara untuk memprediksi atau menngelompokkan yang sangat kuat. Rumus algoritma C4.5 terbagi menjadi 2 rumus yaitu untuk mencari nilai gain dan untuk mencari nilai entropy. Algoritma C4.5 merupakan pengembangan dari algoritma ID3, Proses pada pohon keputusan adalah mengubah bentuk data (tabel) menjadi model pohon, mengubah model pohon menjadi rule, dan menyederhanakan rule. Cabang-cabang dari pohon keputusan merupakan pertanyaan klasifikasi sedangkan untuk daundaunnya merupakan kelas-kelas atau kelompoknya. Karena tujuan dari algortima C4.5 untuk melakukan klasifikasi, sehingga hasil dari pengolahan dataset berupa pengelompokan data ke dalam kelas-kelas tertentu [9][10][11]. Secara umum algoritma C4.5 untuk membangun pohon keputusan adalah sebagai berikut :

1) Pilih atribut sebagai akar

2) Buat cabang untuk tiap tiap cabang

3) Bagi kasus dalam cabang

4) Ulangi proses untuk setiap cabang sampai semua kasus pada cabang memiliki kelas yang sama

a) Konsep Entropy

Entropy (S) merupakan jumlah bit yang diperkirakan dibutuhkan untuk dapat mengekstrak suatu kelas (+ atau -) dari sejumlah data acak pada ruang sampel S. Entropy dapat dikatakan sebagai kebutuhan bit untuk menyatakan suatu kelas.Entropy digunakan untuk mengukur ketidakaslian S. Untuk perhitungan nilai Enthopy sebagai berikut:

Enthopy $(s)=\sum_{i=1}^{n}-\rho \mathrm{i} * \log _{2} \rho i$

Keterangan :

$\mathrm{S} \quad$ : Himpunan kasus.

A : Fitur.

n : Jumlah Partisi S.

pi $\quad$ proporsi dari $s_{i}$ terhadap $\mathrm{S}$

b) Konsep Gain

Gain $(S, A)$ merupakan perolehan informasi dari atribut A relative terhadap output data S. Perolehan informasi didapat dari output data atau variable dependent $\mathrm{S}$ yang dikelompokkan berdasarkan atribut A, dinotasikan dengan gain $(\mathrm{S}, \mathrm{A})$. Untuk memilih atribut sebagai akan didasarkan pada nilai gain tertinggi dari atribut-atribut yang ada. Dengan rumus sebagai berikut : 


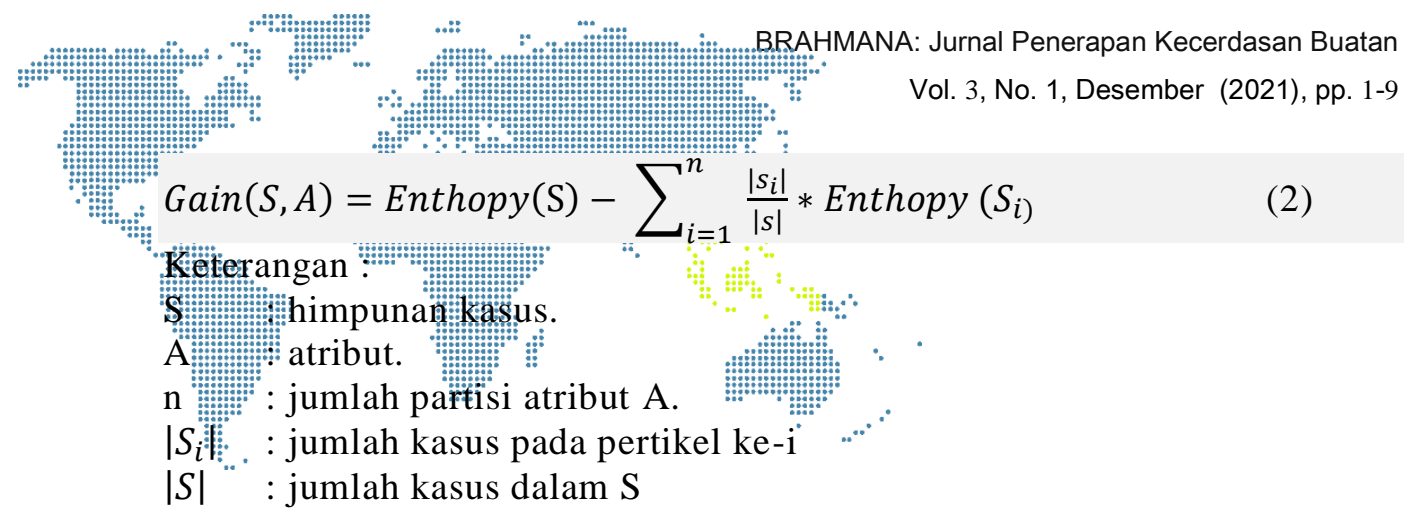

\section{Hasil dan Pembahasan}

Penelitian inin dilakukan di wilayah Desa Pamatang Purba. Data penelitian yang digunakan adalah data yang sudah ada pada Kantor Lurah Pamatang Purba dan Wawancara langsung kepada warga dalam proses pengumpulan data. Berikut adlaah data penelitian yang digunakan.

Tabel 1. Tabel Data Penerima Bantuan Tahun 2020/2021

\begin{tabular}{|c|c|c|c|c|c|c|c|c|}
\hline No & Nama & $\begin{array}{l}\text { Penghasilan } \\
\text { /Bulan(Rp) }\end{array}$ & Umur & $\begin{array}{c}\text { Status } \\
\text { Pernikahan }\end{array}$ & Pekerjaan & $\begin{array}{c}\text { Penerima } \\
\text { Bansos }\end{array}$ & $\begin{array}{c}\text { Penerima } \\
\text { Bpjs }\end{array}$ & $\begin{array}{c}\text { Penerima } \\
\text { Blt }\end{array}$ \\
\hline 1 & $\begin{array}{l}\text { Jamaner } \\
\text { Sinaga }\end{array}$ & 1.000 .000 & 68 & Duda & Bertani & Tidak & Iya & Iya \\
\hline 2 & $\begin{array}{l}\text { Firman } \\
\text { Muller } \\
\text { Purba }\end{array}$ & 1.000 .000 & 65 & Menikah & Buruh & Iya & Tidak & Iya \\
\hline 3 & $\begin{array}{l}\text { Jason } \\
\text { Sinaga }\end{array}$ & 500.000 & 75 & Duda & Bertani & Tidak & Tidak & Tidak \\
\hline 4 & $\begin{array}{l}\text { Marudin } \\
\text { Damanik }\end{array}$ & 700.000 & 69 & Duda & Bertani & Iya & Iya & Iya \\
\hline 5 & $\begin{array}{l}\text { Sintaini } \\
\text { m Purba }\end{array}$ & 400.000 & 85 & Janda & Buruh & Iya & Tidak & Iya \\
\hline 6 & $\begin{array}{l}\text { Salamat } \\
\text { Purba } \\
\text { Tondang }\end{array}$ & 500.000 & 72 & Menikah & Bertani & Tidak & Tidak & Tidak \\
\hline 7 & $\begin{array}{l}\text { Jonalma } \\
\text { n Sinaga }\end{array}$ & 1.500 .000 & 35 & Menikah & Wiraswasta & Tidak & Iya & Iya \\
\hline 8 & $\begin{array}{l}\text { Febriant } \\
\text { o Sinaga }\end{array}$ & 2.000 .000 & 40 & Menikah & Bertani & Tidak & Tidak & Tidak \\
\hline 9 & $\begin{array}{l}\text { Lencon } \\
\text { Sinaga }\end{array}$ & 1.000 .000 & 52 & Duda & Wiraswasta & Iya & Tidak & Tidak \\
\hline 10 & $\begin{array}{l}\text { Jonelma } \\
\mathrm{n} \\
\text { Saragih }\end{array}$ & 2.500 .000 & 30 & Menikah & Wiraswasta & Tidak & Iya & Iya \\
\hline$\cdots$ & $\cdots$ & $\cdots$ & $\cdots$ & $\cdots$ & $\cdots$ & $\cdots$ & $\cdots$ & $\cdots$ \\
\hline 47 & $\begin{array}{l}\text { Erni } \\
\text { Trianita } \\
\text { Saragih }\end{array}$ & 1.000 .000 & 65 & Janda & Buruh & Tidak & Iya & Iya \\
\hline 48 & $\begin{array}{l}\text { Lamria } \\
\text { Purba }\end{array}$ & 1.000 .000 & 58 & Janda & Buruh & Tidak & Tidak & Tidak \\
\hline 49 & $\begin{array}{l}\text { Jimat } \\
\text { Silalahi }\end{array}$ & 2.000 .000 & 60 & Menikah & Buruh & Iya & Tidak & Tidak \\
\hline 50 & $\begin{array}{l}\text { Homaria } \\
\text { Sinaga }\end{array}$ & 1.000 .000 & 50 & Janda & Bertani & Iya & Tidak & Tidak \\
\hline
\end{tabular}

Dalam menentukan hasil model aturan pertama yang menggunakan Data Mining dengan Algoritma C4.5. Algoritma C4.5 dilakukan untuk memberikan model aturan dari data yang digunakan. Berikut ini langkah-langkah dalam membentuk pohon keputusan dengan menggunakan Algoritma C4.5: 


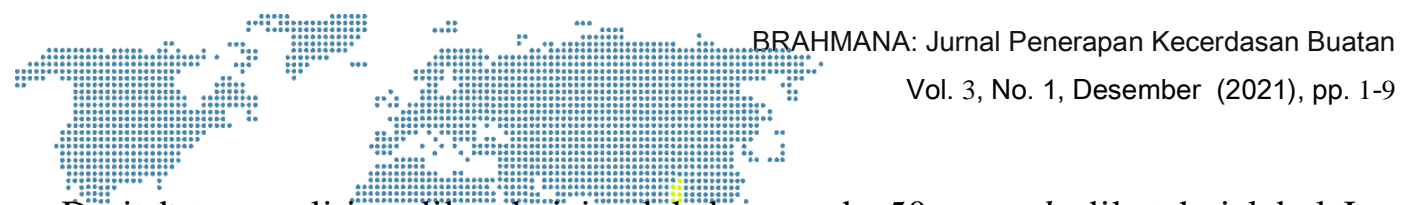

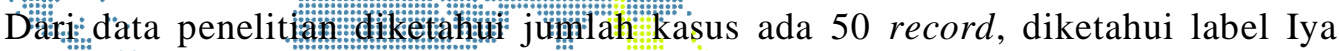

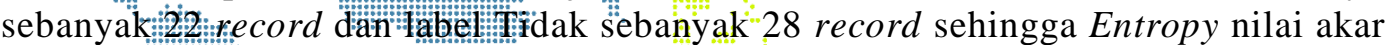
total yanom tieteipat:

Entropyss: $\sum_{i=1}^{n}-p i$ *

$$
\begin{aligned}
& \text { He }(-22 / 50 . \log 2(22 / 50))+(-28 / 50 \ldots \log 2(28 / 50))
\end{aligned}
$$

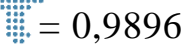

Menghitung nilai Entropy pada atribut Penghasilan Perbulan dengan kategori Dibawah 1 Juta, jumlah kasus terdapat 16 record, terdapat label Iya sebanyak 6 record dan label Tidak sebanyak 10 record.

$$
\begin{aligned}
\operatorname{Entropy}(S) & =\sum_{i=1}^{n}-p i * \log _{2} p i \\
& =(-6 / 16 \cdot \log 2(6 / 16))+(-10 / 16 \cdot \log 2(10 / 16)) \\
& =0,9544
\end{aligned}
$$

Seterusnya perhitungan Entropy pada atribut Penghasilan Perbulan sampai dengan kategori Diatas 2 Juta. Selanjutnya menghitung nilai Gain pada Atribut Penghasilan Perbulan dengan kategori Dibawah 1 Juta terdapat 16 record, kategori Lebih 1 Juta sampai Dibawah 2 Juta terdapat 28 record, dan kategori Diatas 2 Juta terdapat 6 record:

$$
\begin{aligned}
\operatorname{Gain}(S, A)= & \operatorname{Entropy}(S)-\sum_{i-1}^{n} \frac{|S i|}{|S|} * \operatorname{Entropy}(S i) \\
= & 0,9896-(((16 / 50) * 0,9544)+((28 / 50) * 0,9852)+ \\
& ((6 / 50) * 0,9183)) \\
= & 0,0222
\end{aligned}
$$

Selanjutnya Menghitung SplitInfo pada atribut Penghasilan Perbulan berdasarkan jumlah kasus pada Penghasilan Perbulan.

\begin{tabular}{|c|c|c|c|c|c|c|c|c|c|}
\hline No & Atribut & & $\begin{array}{l}\text { Jumlah } \\
\text { Kasus }\end{array}$ & Iya & Tidak & Entropy & Gain & $\begin{array}{l}\text { Split } \\
\text { Info }\end{array}$ & $\begin{array}{l}\text { Gain } \\
\text { Ratio }\end{array}$ \\
\hline \multirow{4}{*}{1} & Total & & 50 & 22 & 28 & 0,9896 & & & \\
\hline & Penghasilan & & & & & & 0,0222 & 1,3615 & 0,0163 \\
\hline & Perbulan & $<=1$ Juta & 16 & 6 & 10 & 0,9544 & & & \\
\hline & & $\begin{array}{l}>1 \text { juta } \\
\text { sampai }<2 \\
\text { juta }\end{array}$ & 28 & 12 & 16 & 0,9852 & & & \\
\hline \multirow{4}{*}{2} & & $>2$ juta & 6 & 4 & 2 & 0,9183 & & & \\
\hline & Umur & & & & & & 0,0002 & 0,7602 & 0,0002 \\
\hline & & Tua & 39 & 17 & 22 & 0,9881 & & & \\
\hline & & Dewasa & 11 & 5 & 6 & 0,9940 & & & \\
\hline \multirow[t]{4}{*}{3} & Pernikahan & & & & & & 0,0191 & 1,3593 & 0,0141 \\
\hline & & Menikah & 30 & 12 & 18 & 0,9710 & & & \\
\hline & & Duda & 8 & 5 & 3 & 0,9544 & & & \\
\hline & & Janda & 12 & 5 & 7 & 0,9799 & & & \\
\hline \multirow[t]{4}{*}{4} & Pekerjaan & & & & & & 0,1478 & 1,4913 & 0,0991 \\
\hline & & Bertani & 23 & 5 & 18 & 0,7554 & & & \\
\hline & & Buruh & 18 & 10 & 8 & 0,9911 & & & \\
\hline & & Wiraswasta & 9 & 7 & 2 & 0,7642 & & & \\
\hline \multirow[t]{2}{*}{5} & Penerima & & & & & & 0,0059 & 0,9954 & 0,0060 \\
\hline & Bansos & Iya & 23 & 9 & 14 & 0,9656 & & & \\
\hline
\end{tabular}

$$
\begin{aligned}
\text { SplitInfo }= & \sum_{i=1}^{k} p\left(v_{i} \mid s\right) \log _{2} p\left(v_{i} \mid s\right) \\
= & -((16 / 50 . \log 2(16 / 50))+(28 / 50 . \log 2(28 / 50)+(6 / 50 . \log 2 \\
& (6 / 50))) \\
= & 1,3615
\end{aligned}
$$

Kemudian menghitung Nilai GainRatio Penghasilan Perbulan sebagai nilai yang digunakan sebagai pemecahan Node pada pohon keputusan.

$$
\begin{gathered}
\operatorname{RasioGain}(s, j)=\frac{\operatorname{Gain}(s, j)}{\operatorname{SplitInfo}(s, j)} \\
=0,0222 / 1,3615=0,0163
\end{gathered}
$$

Hasil dari perhitungan nilai Entropy, nilai Gain, SplitInfo dan GainRatio untuk tiap atribut dapat dilihat pada Tabel 2 sebagai berikut :

Tabel 2. Perhitungan Gain Node 1 


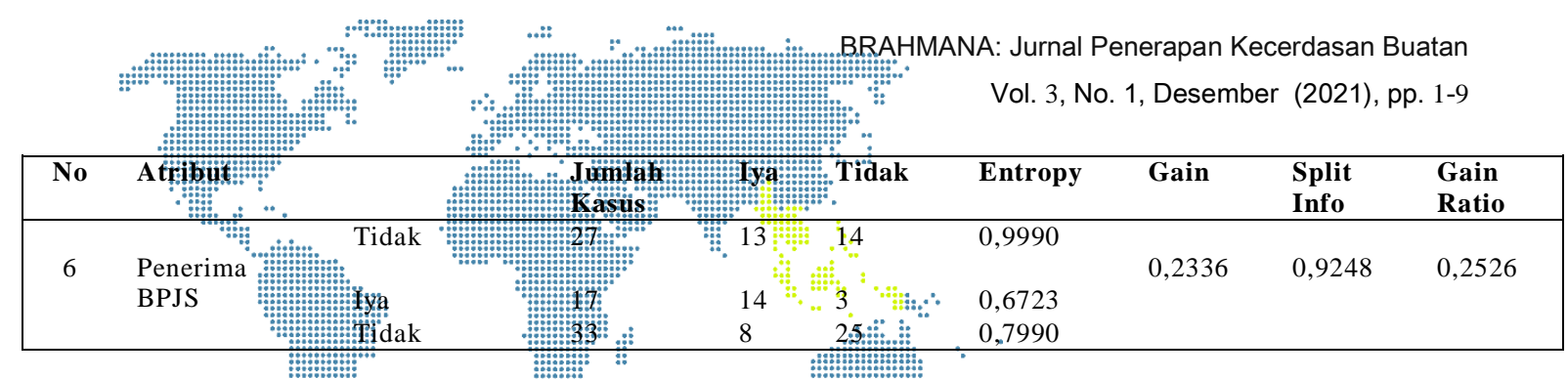

Dari Tabel 2 diketahui nilai GainRatio terbesar adalah atribut Penerima BPJS dengan nilaì.. 0,2526 dengan kategori Iya dengan nilai 0,6723 dan kategori Tidak dengan nilai 0,7990 dan dijadikan simpul akar untuk mengulangi perhitungan nilai Entropy dan nilai Gain selanjutnya. Hasil perhitungan nilai Entropy dan nilai Gain untuk atribut Penerima BPJS untuk kategori Iya, dapat dilihat pada Tabel 3. berikut:

Tabel 3. Dari Tabel 2 diketahui nilai GainRatio terbesar adalah atribut Penerima BPJS dengan nilai 0,2526 dengan kategori Iya dengan nilai 0,6723 dan kategori Tidak dengan nilai 0,7990 dan dijadikan simpul akar untuk mengulangi perhitungan nilai Entropy dan nilai Gain selanjutnya. Hasil perhitungan nilai Entropy dan nilai Gain untuk atribut Penerima BPJS untuk kategori Iya, dapat dilihat pada Tabel 3. berikut:

Tabel 3. Perhitungan Gain Node 1.1

\begin{tabular}{|c|c|c|c|c|c|c|c|c|c|}
\hline No & Atribut & & $\begin{array}{l}\text { Jumlah } \\
\text { Kasus }\end{array}$ & Iya & Tidak & Entropy & Gain & $\begin{array}{l}\text { Split } \\
\text { Info }\end{array}$ & $\begin{array}{l}\text { Gain } \\
\text { Ratio }\end{array}$ \\
\hline \multirow{4}{*}{1} & \multicolumn{2}{|c|}{ Total } & 17 & 14 & 3 & 0.6723 & \multirow{4}{*}{0,0768} & \multirow{4}{*}{1,4681} & \multirow{4}{*}{0,0523} \\
\hline & Penghasilan & & & & & & & & \\
\hline & \multirow{3}{*}{ Perbulan } & $<=1 \mathrm{Juta}$ & 4 & 3 & 1 & 0,8113 & & & \\
\hline & & $\begin{array}{l}>1 \text { juta } \\
\text { sampai < } 2 \\
\text { juta }\end{array}$ & 9 & 7 & 2 & 0,7642 & & & \\
\hline \multirow{4}{*}{2} & & $>2$ juta & 4 & 4 & 0 & 0,0000 & \multirow{3}{*}{0,0078} & \multirow{3}{*}{0,7871} & \multirow{4}{*}{0,0099} \\
\hline & \multirow[t]{3}{*}{ Umur } & & & & & & & & \\
\hline & & Tua & 13 & 11 & 2 & 0,6194 & & & \\
\hline & & Dewasa & 4 & 3 & 1 & 0,8113 & \multirow{5}{*}{0,1253} & \multirow{4}{*}{1,2896} & \\
\hline \multirow[t]{4}{*}{3} & \multirow{4}{*}{ Pernikahan } & & & & & & & & \multirow{4}{*}{0,0972} \\
\hline & & Menikah & 11 & 8 & 3 & 0,8454 & & & \\
\hline & & Duda & 3 & 3 & 0 & 0,0000 & & & \\
\hline & & Janda & 3 & 3 & 0 & 0,0000 & & \multirow{4}{*}{1,4958} & \\
\hline \multirow[t]{4}{*}{4} & \multirow[t]{4}{*}{ Pekerjaan } & & & & & & \multirow{4}{*}{0,2666} & & \multirow[t]{4}{*}{0,1782} \\
\hline & & Bertani & 7 & 4 & 3 & 0,9852 & & & \\
\hline & & Buruh & 3 & 3 & 0 & 0,0000 & & & \\
\hline & & Wiraswasta & 7 & 7 & 0 & 0,0000 & & \multirow{4}{*}{0,8740} & \\
\hline \multirow[t]{3}{*}{5} & Penerima & & & & & & \multirow{3}{*}{0,0946} & & \multirow[t]{3}{*}{0,1083} \\
\hline & Bansos & Iya & 5 & 3 & 2 & 0,9710 & & & \\
\hline & & Tidak & 12 & 11 & 1 & 04138 & & & \\
\hline
\end{tabular}

Dari Tabel 3 diketahui nilai GainRatio terbesar adalah atribut Pekerjaan dengan nilai 0,1782 dengan kategori Bertani dengan nilai 0,9852, kategori Buruh dengan nilai 0,0000 dan kategori Wiraswasta dengan nilai 0,0000 dan dijadikan simpul akar untuk mengulangi perhitungan nilai Entropy dan nilai Gain selanjutnya pada kategori Bertani. Perhitungan dilakukan hingga diperoleh hasil gain node 1.2.1.1.2 sebagai berikut:

Tabel 4. Perhitungan Gain Node 1.2.1.1.2

\begin{tabular}{|c|c|c|c|c|c|c|c|c|c|}
\hline No & Atribut & & $\begin{array}{l}\text { Jumlah } \\
\text { Kasus }\end{array}$ & Iya & Tidak & Entropy & Gain & $\begin{array}{l}\text { Split } \\
\text { Info }\end{array}$ & $\begin{array}{l}\text { Gain } \\
\text { Ratio }\end{array}$ \\
\hline \multirow{3}{*}{1} & Total & & 4 & 1 & 3 & 0,8113 & \multirow{3}{*}{0,0000} & \multirow{3}{*}{0,0000} & \multirow{3}{*}{0,0000} \\
\hline & Penghasila & & & & & & & & \\
\hline & Perbulan & $<=1$ Juta & 4 & 1 & 3 & 0,8113 & & & \\
\hline \multirow{5}{*}{2} & & $\begin{array}{l}>1 \text { juta } \\
\text { sampai }<2 \\
\text { juta }\end{array}$ & 0 & 0 & 0 & 0,0000 & \multirow{5}{*}{0,3113} & \multirow{5}{*}{1,0000} & \multirow{5}{*}{0,3113} \\
\hline & & $>2$ juta & 0 & 0 & 0 & 0,0000 & & & \\
\hline & Penerima & & & & & & & & \\
\hline & Bansos & Iya & 2 & 1 & 1 & 1,0000 & & & \\
\hline & & Tidak & 2 & 0 & 2 & 0,0000 & & & \\
\hline
\end{tabular}




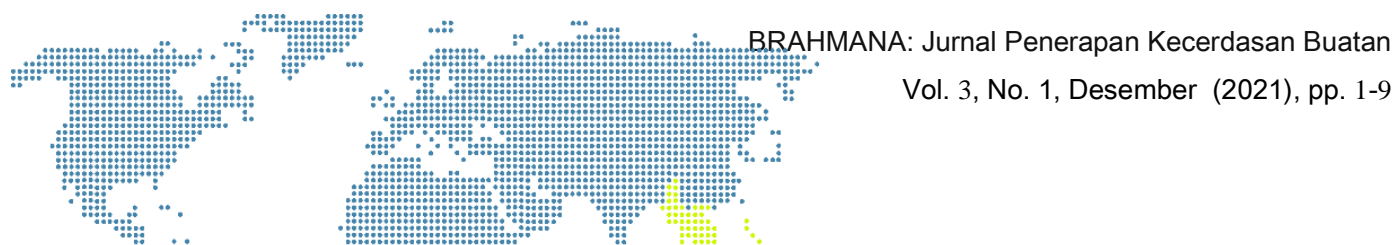

Dari TTabet 4 diketahtu nitalit! GainRatio terbesar adalah atribut Penerima Bansos

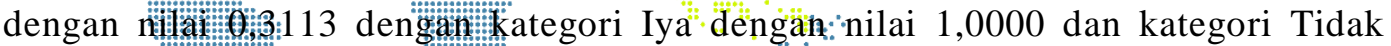

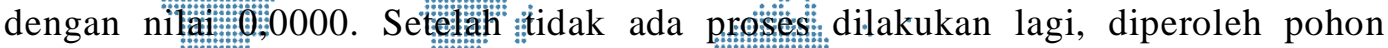
keputusan yang dapat dilihat pada Gambar 2 bermut :

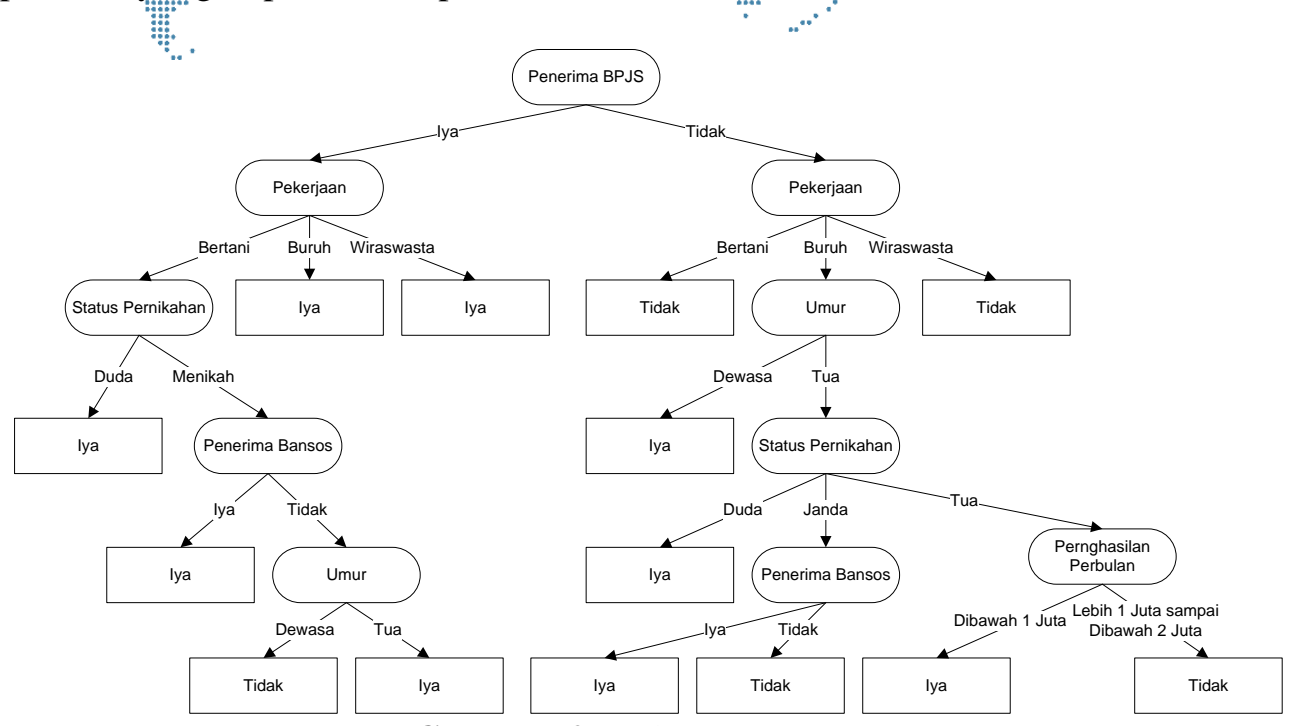

Gambar 2. Pohon Keputusan

Berdasarkan bentuk pohon keputusan pada gambar 2, aturan atau Rule model yang didapatkan adalah sebagai berikut :

1) Jika Penerima BPJS = Iya, Pekerjan = Bertani, dan Status Pernikahan = Duda, maka hasilnya $=$ Iya $($ Iya $=2$ dan Tidak $=0)$

2) Jika Penerima BPJS = Iya, Pekerjan = Bertani, dan Status Pernikahan = Menikah, dan Penerima Bansos $=$ Iya, maka hasilnya $=$ Tidak $($ Iya $=0$ dan Tidak = 2)

3) Jika Penerima BPJS = Iya, Pekerjan = Bertani, dan Status Pernikahan = Menikah, Penerima Bansos $=$ Tidak dan Umur $=$ Dewasa, maka hasilnya $=$ Tidak (Iya $=1$ dan Tidak $=1)$

4) Jika Penerima BPJS = Iya, Pekerjan = Bertani, dan Status Pernikahan = Menikah, Penerima Bansos = Tidak dan Umur = tua, maka hasilnya = Iya $($ Iya $=1$ dan Tidak $=0)$

5) Jika Penerima BPJS = Iya dan Pekerjaan = Buruh, maka hasilnya = Iya (Iya $=3$ dan Tidak $=0$ )

6) Jika Penerima BPJS = Iya dan Pekerjaan = Wiraswasta, maka hasilnya $=$ Iya $($ Iya $=7$ dan Tidak $=0)$

7) Jika Penerima BPJS = Tidak dan Pekerjaan = Petani, maka hasilnya $=$ Tidak $($ Iya $=1$ dan Tidak $=15)$

8) Jika Penerima BPJS $=$ Tidak, Pekerjaan $=$ Petani dan Umur $=$ Dewasa, maka hasilnya $=$ Iya $($ Iya $=2$ dan Tidak $=0)$

9) Jika Penerima BPJS $=$ Tidak, Pekerjaan $=$ Buruh, Umur $=$ Tua dan Status Pernikahan $=$ Duda, maka hasilnya $=$ Iya $($ Iya $=2$ dan Tidak $=1)$

10) Jika Penerima BPJS $=$ Tidak, Pekerjaan $=$ Buruh, Umur $=$ Tua, Status Pernikahan $=$ Janda dan Penerima Bansos $=$ Iya, maka hasilnya $=$ Iya $($ Iya $=$ 1 dan Tidak =1)

11 $)$ Jika Penerima BPJS $=$ Tidak, Pekerjaan $=$ Buruh, Umur $=$ Tua, Status Pernikahan $=$ Janda dan Penerima Bansos $=$ Tidak, maka hasilnya $=$ Tidak $($ Iya $=0$ dan Tidak $=2)$ 


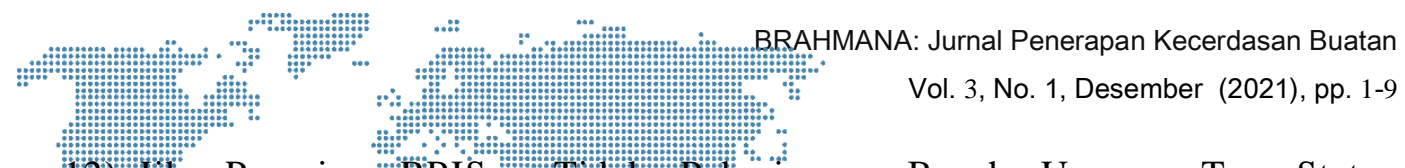

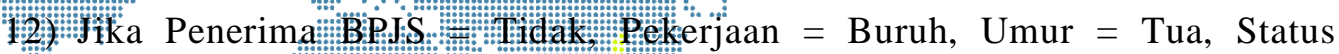

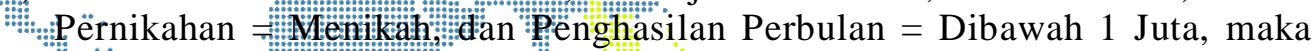

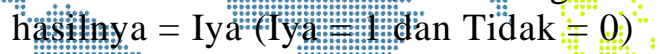

13) Jika Penerima BPIS S Tidak, Pekerjah: = Buruh, Umur = Tua, Status Pernomathan = Mein

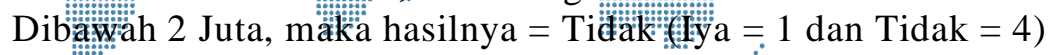

14) Jika hasilnya $=$ Tidak $($ Iya $=0$ dan Tidak $=2)$

Hasil yang dilakukan penulis dalam perhitungan Algoritma C4.5 menghasilkan model aturan dengan penerima BLT tertinggi adalah Jika Penerima BPJS = Iya dan Pekerjaan $=$ Wiraswasta, maka hasilnya Iya dengan perolehan label Iya sebanyak 7 item dan Tidak sebanyak 0 item.

Hasil yang diberikan oleh tools RapidMiner Algoritma C4.5 menghasilkan model aturan dengan penerima BLT tertinggi adalah Jika Penerima BPJS = Iya dan Pekerjaan $=$ Wiraswasta, maka hasilnya Iya dengan perolehan label Iya sebanyak 7 item dan Tidak sebanyak 0 item. Artinya Hasil dari proses yang dilakukan penulis dan tools RapidMiner untuk Algoritma C4.5 adalah sama dan valid.

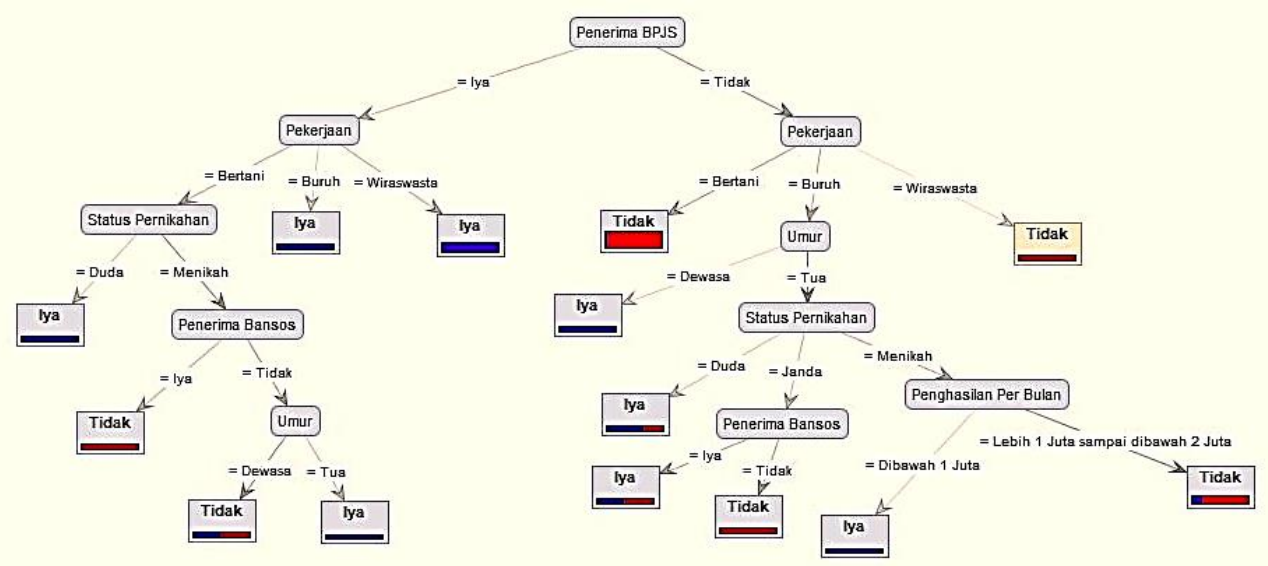

Gambar 3. Tampilan Pohon Keputusan

\section{Kesimpulan}

Berdasarkan hasil penelitian yang dilakukan, penulis menarik beberapa kesimpulan diantaranya:

1. Data mining dengan menggunakan algoritma C4.5 dapat diterapkan.

2. Hasil yang didapatkan oleh penulis dan tools RapidMiner adalah Algoritma C4.5 menghasilkan model aturan penerima BLT tertinggi adalah Jika Penerima BPJS = Iya dan Pekerjaan = Wiraswasta, maka hasilnya Iya dengan perolehan label Iya sebanyak 7 item dan Tidak sebanyak 0 item. Sehingga dari hasil algoritma tersebut dapat memberikan rekomendasi untuk pengambil keputusan kepada Kepala Desa Pamatang Purba untuk memberikan BLT Secara merata berdasarkan model yang diberikan.

\section{Daftar Pustaka}

[1] K. Fatmawati And A. P. Windarto, "Data Mining: Penerapan Rapidminer Dengan K-Means Cluster Pada Daerah Terjangkit Demam Berdarah Dengue ( Dbd ) Berdasarkan Provinsi," Vol. 3, No. 2, Pp. 173-178, 2018.

[2] D. N. Batubara And A. P. Windarto, "Analisa Klasifikasi Data Mining Pada Tingkat Kepuasan Pengunjung Taman Hewan Pematang Siantar Dengan Algoritma," Komik (Konferensi Nas. Teknol. Inf. Dan Komputer), Vol. 3, No. 1, 


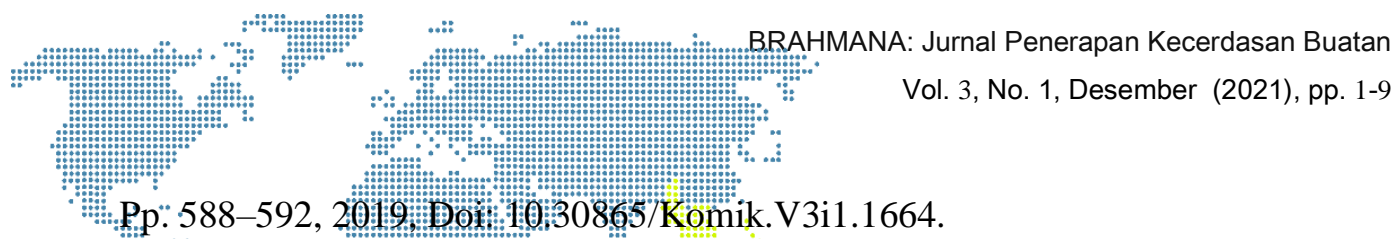

[3] M"

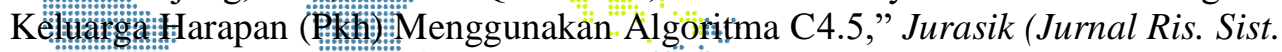

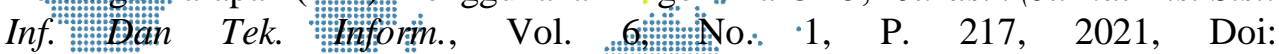

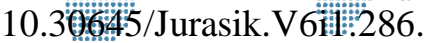

[4] B. Novianti, T. Rismawan, And S. Bahri, "Implementasi Data Mining Dengan Algoritma C4.5 Untuk Penjurusan Siswa (Studi Kasus: Sma Negeri 1 Pontianak)," J. Coding, Sist. Komput. Untan, Vol. 04, No. 3, Pp. 75-84, 2016.

[5] A. Annurullah Fajrin And A. Maulana, "Penerapan Data Mining Untuk Analisis Pola Pembelian Konsumen Dengan Algoritma Fp- Growth Pada Data Transaksi Penjualan," Kumpul. J. Ilmu Komput., Vol. 05, No. 01, Pp. 27-36, 2018.

[6] T. Wibowo, "Penerapan Data Mining Pemilihan Siswa Kelas Unggulan Dengan Metode K-Means Clustering Di Smp N 02 Tasikmadu," 2018.

[7] Ari Budiono, "Pohon Keputusan Dengan Algoritma C4.5 1.," Pp. 3-4, 2017.

[8] A. Chandra, "Penerapan Data Mining Menggunakan Pohon Keputusan," Vol. 6, No. 3, Pp. 1-6, 2017.

[9] N. Azwanti, "Analisa Algoritma C4.5 Untuk Memprediksi Penjualan Motor Pada Pt. Capella Dinamik Nusantara Cabang Muka Kuning," Inform. Mulawarman J. Ilm. Ilmu Komput., Vol. 13, No. 1, P. 33, 2018, Doi: 10.30872/Jim.V13i1.629.

[10] R. Wajhillah And I. Yulianti, "Penerapan Algoritma C4.5 Untuk Prediksi Penggunaan Jenis Kontrasepsi Berbasis Web," Klik - Kumpul. J. Ilmu Komput., Vol. 4, No. 2, P. 160, 2017, Doi: 10.20527/Klik.V4i2.98.

[11] D. R. Sitorus, A. P. Windarto, D. Hartama, And I. S. Damanik, "Penerapan Klasifikasi C4.5 Dalam Meningkatkan Sistem Pembelajaran Mahasiswa," Komik (Konferensi Nas. Teknol. Inf. Dan Komputer), Vol. 3, No. 1, Pp. 593-597, 2019, Doi: 10.30865/Komik.V3i1.1665. 